\title{
Shoppers' Perception on Physical Condition of Shopping Centers' Atmosphere at Different Lifecycle
}

\author{
Astrid Kusumowidagdo*, Agus Sachari**, Pribadi Widodo*** \\ "Universitas Ciputra, Surabaya \\ ${ }^{* * *, * * *}$ Institut Teknologi Bandung, Bandung
}

ARTICLE INFO ABSTRACT

Received: February 05, 2012

Final revision: July 11, 2012

\section{Keywords:}

atmospheric stimuli,

design features,

consumer behavior,

shopping center lifecycle

\begin{abstract}
Shopping center with atmospheric stimuli design needs to be well formulated in marketing strategy to expose its competitive advantage. As a result, most designs included in the marketing tactic scheme pay more attention to all factors related to the lifestyle in order to make designs exist and be appreciated by the society. Design is one of the key factors of shopping center to gain its success. This research aimed to find out to what extent the visitors perception is different towards shopping centers which has different lifecycles. The research studied two things, first was exploratory research intended to find the embodiment of atmospheric (atmospheric variables).The second research was done in a quantitative method, (multiple regression). This research studied the perception of a hundred mall visitors regarding how the variables of the interior atmosphere affected their shopping habit. The independent variables in the research were the exterior features and building configuration, interior features and supporting facilities. The dependent variable was the the visitor behavior. As a conclusion, the atmospheric interior design of a mall that is embodied in its interior element supported the hypothesis which said that existence of experience which felt differently according to visitor perception at shopping centers in different lifecyle.
\end{abstract}

(C) 2012 IRJBS, All rights reserved. $\mathrm{n}$ their development shopping centers can accommodate the characteristics of the modern people. They are becoming a place where everyone can easily find their spaces. In addition to making it easier for the people to do their activities inside the premises, the one stop shopping point concept is a form of comfort offered by the modern shopping center as a direct response to the demands of the increasingly faster and more challenging life. Therefore, in review, the modern society is spending more of their time inside a shopping center. With various descriptions 
mentioned above, it is evident that the activities inside the mall are no longer about functional shopping with personal motive. Therefore it is fitting to say that as the place where urban people do their activities, a shopping center functions as a transactional space as well as a space for social purposes and also a liminal space. In addition to being a place for purchasing items, a shopping center has several additional functions including shopping and social activities (Abaza, 2001).

As a transactional space, a shopping center has a lot of plus points because a comfortable design provides both trading and recreational functions. It also offers ease of shopping, saves time and cost o search. As a social interaction space, the presence of a shopping center really helps. The location of a shopping center is usually carefully chosen by the developer to make sure that it is strategically located and easy to reach. A shopping center is also equipped with various forms of open plaza or atrium to replace town square as community space although it is not as open as other public areas.

Open plaza and atrium here function as a receptacle for various cultural activities, both from and for the community, socially as well as in the function of product placement. An open plaza provides a location to interact for differen communities. In addition, there are several place inside a shopping center, such as food court, which is used as the location for the city communities to independently socialize with one another. The phenomenon of the modern shopping cente which also serves as a public space similar to town squares, city parks and streets, among others, has also been stated by Staeheli and Mitchel (2006). In some cases, a shopping center has replicated these conditions to such extend that it resemble shopping town in a smaller scale.

As stated by Goss (2007), a shopping center is a market place where various kinds of humanity keep evolving, starting from the attractive objects on offer to the energy or spirit obtained from gathering masses where a lot of unexpected adventures, encounter and community, happen. (Bakhtin on Goss, 2007).

On the one hand, the rapid growth of retail transactional value in Indonesia is estimated to skyrocket from US\$135 billion in 2011 to US\$223 billion in 2015, establishing the stronger position Indonesia has in the field of retail. Coupled with the high level of trust among people in the property business, the investment level in Indonesia is expected to stay positive. Considering the abovementioned prediction, the growth of the Indonesian shopping center is certain. The existence of a shopping center will provide a positive contribution towards local as well as national economic development. On the other hand, regarding society as consumers, AC Nielsen Survey (The Marketeers, November 2011) stated that Indonesia placed third out of 56 countries on the list of Consumer Confidence Index. Indonesia was behind India and Saudi Arabia but had a position higher than Singapore, China and the USA. It means that the people of Indonesia, with a sample of $86 \%$ from the respondents, stated that their economic condition and shopping activities would be fine during the year 2012 .

Next, an additional survey by AC Nielsen (Marketing Mix, 2009) disclosed that $93 \%$ of the Indonesian people consider shopping centers as a place for recreation. It can be concluded that for the Indonesian people a shopping center that provides a different experience, mostly in their physical design, is highly expected, just like what's being offered by modern shopping centers today. It is in line with the term coined by Pine and Gilmore (1998) to describe the present time, experience economy, where the functional need of a product will shift to make place for the value obtained by users as well as consumption value based on lifestyle and experience.
Therefore, in this line of thought, a shopping center is the right answer for a distribution receptacle in the retailer level that directly relates to customers. The packaging of an object, in this case a shopping center, brings added value to retailers' products. Shopping center as a design product must function as a creator of experience that can suit the current condition of the people, both for economic benefit (product differentiation and profit) as well as emotional benefit that is generated by the users, which in this context are visitors as the target market of a shopping center Williams (2006).

\section{Atmosphere of a Shopping Center Affects}

\section{Shoppers' Behavio}

According to the Oxford Dictionary, the word of atmosphere has two meanings. The first is denotative, meaning the envelope of gases that surround the earth, while the second has a more connotative meaning, suggesting the mood of a place. Therefore in this context the topic puts an emphasis on layout design. Regarding the level of retail stores, Berman and Evans (2001:604) stated that in the planning of a store's atmosphere design there are several variables that should be taken into account: store exterior, general interior, interior layout and interior display. In shopping centers, we can say that design features comprise exterior, building configuration an interior features (Kramer, 2008). Exterior and building configuration features include building materials, building entrances, canopies, signage, night lighting, truck service facilities, and building configuration. Meanwhile interior features consists of tenant spaces, building flexibility, kiosks, food court, multi levels, storefronts, store size, basement, interior wall, flooring, lighting, heating and air conditioning These two features are integrated and regarded as atmosphere.

Shopping center design creates new experience through the atmosphere that is perceptually felt by the human senses. New forms and concepts as well as creative ideas regarding the creation of experience and how to have a shopping center with a point of interest for consumers should be considered. Similar to a recreational center, a unique design will help tenants creatively create a theatrical store ambience for visitors. This way, visitors can feel the comfort of shopping with more introductions of new experience created by retailers. This experience involves various sensory reactions (for instance visual appearance, sound smell, and texture).

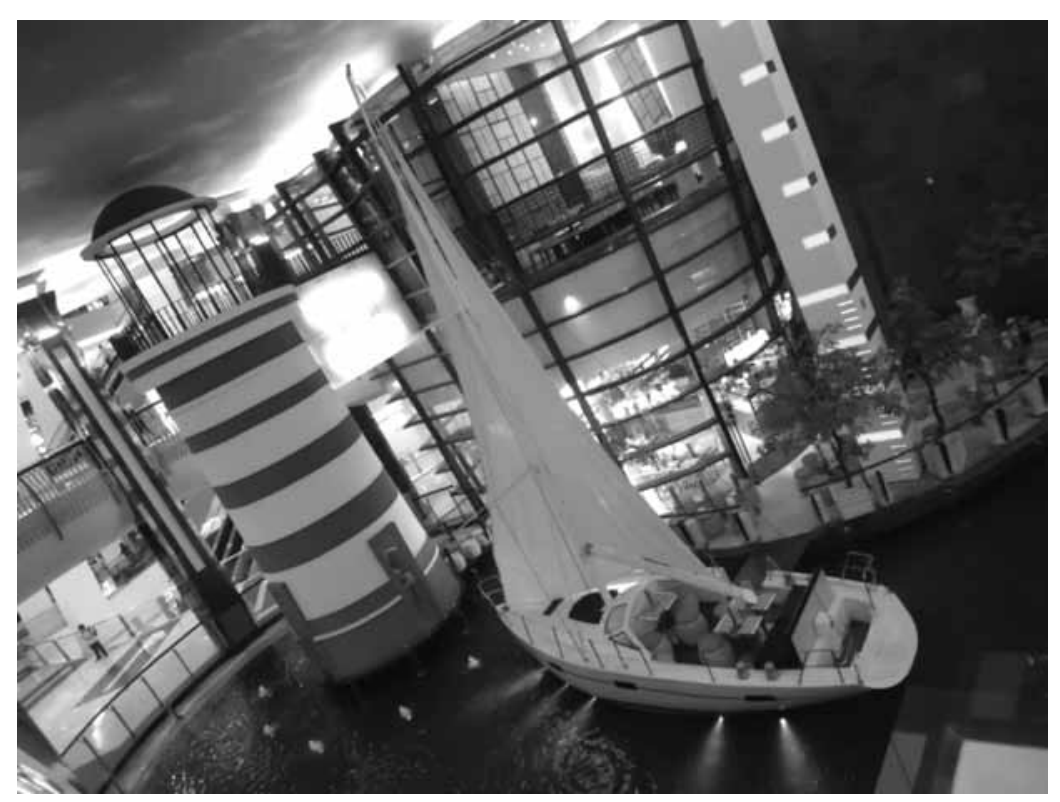

Image 1. Atmosphere that Provides Experience in a Jakarta Shopping Center 
Atmosphere created from a design will provide a sense of place for the location. Atmosphere the acts as a stimulus for visitors so that in the process they will respond through their actions (whether deciding to stay in the shopping center and explore the place or leaving the shopping center). Positive actions from visitors as a result of the appropriate sense of place will provide a deep perception which leads them to go back to the place. A repetitious action to visit a shopping center is a cyclical sequence that induces place attachmen (an emotional bond with a place because of an integrated condition between physical and social surrounding). Cyclical here means activities which are not related to the chronological timeline but more about the significance of meaning and how often the activities are conducted in a certain place (Altman and Low, 1992). In some earlie researches, place attachment in a shopping cente could be seen in visitors who have similar persona concept and lifestyle to the characteristic of the shopping center. Place attachment can happen through the medium of personal and socia meanings if both the physical and social meaning or symbol of a place is in line with one's personal image (sign or locus of the self) (Lavin \& Agatstein 1984; Proshansky.et.all, 1983; Rapoport, 1982s on Altman and Low (1992). Place Attachment. New York Plenum Press, p. 258.

Based on the descriptions above it can be indirectly said that the right shopping center atmosphere can boost the level of attraction, and even influence the next step: the level of attachmen visitors feel towards the shopping center. From the management's perspective, Kotler (1973) stated that the atmospheric condition of a shopping center has several desirable effects on visitors. First, atmosphere can help steer visitors' directio and duration span, thus enhancing probability of purchase. Second, atmosphere can express various characteristics of a shopping center and conjure images for visitors. Lastly, atmospher can provoke emotional reaction from visitors such as excitement and eagerness to look around so that it can be appealing for the shopping center management. This is because, first of all, different from a lot of infue of their control, retailers have the ability to create atmosphere as a controllable variable. Also, this influence can be directed towards visitors with the right target.

With the right design, a shopping behavior can be created. A design functions as a stimulus that affects the behavior.

\section{Atmosphere as Marketing Tactic}

\section{and Shopping Center's Lifecycle}

The success of a shopping center is supported by various factors (Wee and Tong, 2005), including location, visibility, ease of access, dimension, planning and design, anchor tenant, tenant mix, image building strategy, marketing and management, as well as customers' oriented thinking pattern. These nine factors are all interrelated and supportive of one another. Therefore a good design will encourage the shopping center to become visitors' number one choice and place its image according to the required segmenting, targeting and positioning strategy. This way, a design can accommodate marketing activities in each purchasing situation and this will be interesting for the shopping center's customers, including retailers as tenants and the society.

Furthermore, Peter and Olson (2002) divided the five generic situations that affect consumers' shopping behavior into: information obtaining situation, shopping situation, buying situation, consumption situation and throwing away situation. In each stage of situation, a shopping center's design can become a tool to create the best tactic according to strategy.

In information obtaining situation, for instance, consumers find relevant background situation to select their shopping destination. Next, in shopping situation, a design can also act as tactic. Customers

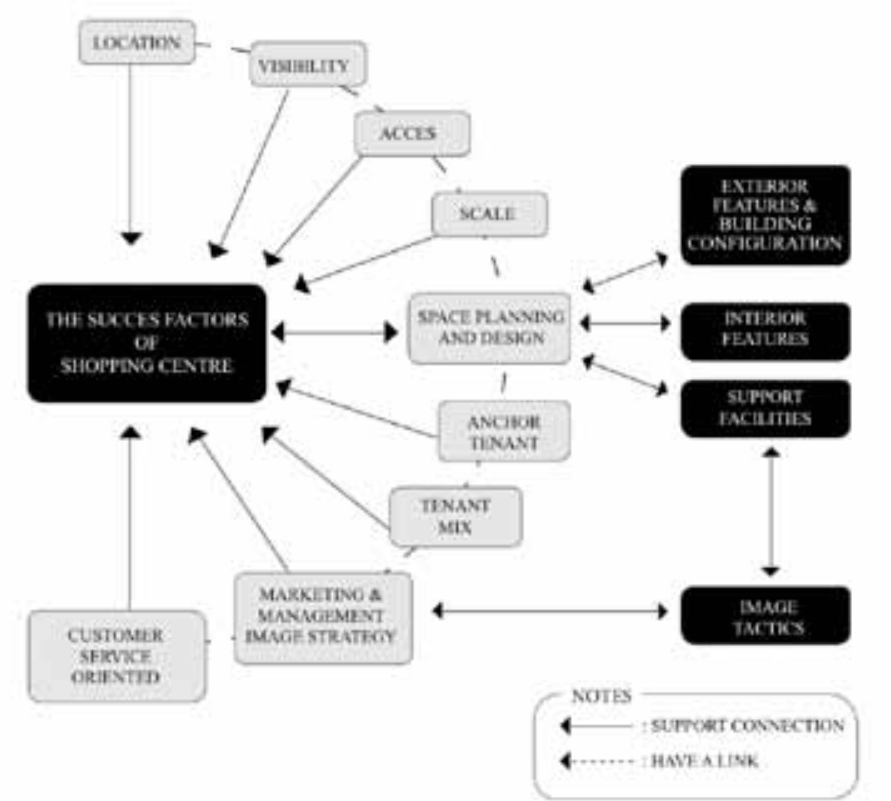

mage 2. The Shopping Center's Nine Keys of Success ource: Wee and Tong, 2005

must easily find products in a store according to their wishes and needs and here the tactic can be implemented-an excellent shopping center layout will certainly boost the visibility of a store. The same thing happens again in each situation so it can be concluded that design is a cohesive tactic in every integrated situation with the presence of various retails. Also, it cannot be related to the lifecycle of the product and shopping center itself.

Regarding marketing, the lifecycle concept can also be applied to shopping center as a business entity (George, 1997; Ferring, 2001:44 on Nicoletta and Christian, 1998). Lifecycle of a shopping center can be divided into innovation (launch), growth (accelerated development), maturity and decline (Berman \& Evans, 2001: 148, Lowry, 1997: 78).

In the innovation stage, the market is still very open and the competition limited, especially when a shopping center offers a new concept. So there is opportunity to rapidly develop and attract a lot of enthusiastic shoppers. The developer usually strives to adjust the initial concept with market demand and attempt to attract visitors with various imaging methods. It will also seek long term lease on high rental rates. Meanwhile, retailers usually try to display early imaging and minimize operationa problems in the opening stage and adjust them to their design and the shop's marketing strategy.

In the accelerated development stage, the marke will develop faster than in the innovation stage. The development will be very popular and will follow the market because of increasing store traffic and sales growth. The developer will keep doing promotional and imaging efforts but fewer than in the previous stage. There will also be maintenance efforts and minor renovations on the building. Retailers will also lower their promotional effort but keep them stabilized and maintain moderate discounts. This is an aggressive adjustment stage between product variety and market demand.

Next in the maturity stage, similar competitor will start to emerge, imitating both the busines concept and building design. Store traffic is getting steady while sales are stable, even slowing down sometimes. Developer will usually push advertising and imaging efforts more to maintain its position, there will be minor renovation works and maintenance. Often in order to maintain 
their position a major renovation or make over is necessary. Tenants will show moderate responses still sticking with products popular with the marke while assuming a more professional conduct.

In the decline stage, the shopping center is at a weakening condition, store traffic is down and the sales growth negative. The developer, should a shopping center reaches this stage, has to do an tenants and visitors. In order to lease spaces, long term is reduced to short term. Retailers usually keep advertising and promotion moderate but conduct extensive sales and price discounts. Shops' dimension will be reduced and the type of store that remains is caretaker stores. extensive reformatting and efforts to keep their

Table 1. Shopping Center Life Cycle

\begin{tabular}{|c|c|c|c|c|c|}
\hline & $\begin{array}{l}\text { Importance } \\
\text { Consideration }\end{array}$ & $\begin{array}{l}\text { Launch/ } \\
\text { Innovation }\end{array}$ & $\begin{array}{l}\text { Growth/ } \\
\text { Accelerated } \\
\text { Development }\end{array}$ & Maturity & Decline \\
\hline \multirow[t]{5}{*}{ Market Factors } & $\begin{array}{l}\text { Number of } \\
\text { Competing } \\
\text { Centers }\end{array}$ & Very few & Rapid Growth & $\begin{array}{l}\text { Many of the } \\
\text { same type of } \\
\text { center }\end{array}$ & $\begin{array}{l}\text { Many of the } \\
\text { same and } \\
\text { newer types }\end{array}$ \\
\hline & $\begin{array}{l}\text { Amount of } \\
\text { shopper trafic } \\
\text { generated }\end{array}$ & Increases rapidly & $\begin{array}{l}\text { Steadily } \\
\text { Increases }\end{array}$ & Stable amount & $\begin{array}{l}\text { Steadily } \\
\text { increases }\end{array}$ \\
\hline & Rate of Sales & Very Rapid & Rapid & $\begin{array}{l}\text { Moderate to } \\
\text { slow }\end{array}$ & $\begin{array}{l}\text { Slow or } \\
\text { Negative }\end{array}$ \\
\hline & Vacancy Rate & Low & Moderate & Moderate & High \\
\hline & $\begin{array}{l}\text { Control Exerted by } \\
\text { Developer }\end{array}$ & Extensive & Moderate & Extensive & Moderate \\
\hline \multirow{5}{*}{$\begin{array}{l}\text { Shopping } \\
\text { Center } \\
\text { Development } \\
\text { Strategies }\end{array}$} & $\begin{array}{l}\text { Advertising and } \\
\text { promotional } \\
\text { activities }\end{array}$ & Extensive & Moderate & Extensive & Moderate \\
\hline & $\begin{array}{l}\text { Renovation of } \\
\text { Facilities }\end{array}$ & None & $\begin{array}{l}\text { Minor } \\
\text { modification }\end{array}$ & $\begin{array}{l}\text { Maintenanece } \\
\text { of Existing } \\
\text { Facilities }\end{array}$ & $\begin{array}{l}\text { Neglect or } \\
\text { extensive } \\
\text { reformating }\end{array}$ \\
\hline & $\begin{array}{l}\text { Effort to attract } \\
\text { new retail tenants }\end{array}$ & Extensive & Moderate & Moderate & Extensive \\
\hline & Rental Rates & High & High & Competitive & Low \\
\hline & Length of Lease & Long & Long & Moderate & Short \\
\hline \multirow[t]{5}{*}{$\begin{array}{l}\text { Retail-Tenant } \\
\text { Strategies }\end{array}$} & $\begin{array}{l}\text { Advertising and } \\
\text { promotional } \\
\text { activities }\end{array}$ & $\begin{array}{l}\text { Extensive to } \\
\text { create awareness }\end{array}$ & $\begin{array}{l}\text { Moderate to } \\
\text { draw greater } \\
\text { interest }\end{array}$ & $\begin{array}{l}\text { Extensive to } \\
\text { compete on } \\
\text { price }\end{array}$ & $\begin{array}{l}\text { Moderate to } \\
\text { remind sale } \\
\text { price }\end{array}$ \\
\hline & $\begin{array}{l}\text { Special sales and } \\
\text { price discounts }\end{array}$ & Few & Moderate & Extensive & Extensive \\
\hline & $\begin{array}{l}\text { Merchandise } \\
\text { offerings }\end{array}$ & $\begin{array}{l}\text { Preplanned } \\
\text { variety and } \\
\text { assortment }\end{array}$ & $\begin{array}{l}\text { Variety and } \\
\text { assortment to } \\
\text { the market }\end{array}$ & $\begin{array}{l}\text { Stable variety } \\
\text { and assortment }\end{array}$ & $\begin{array}{l}\text { Reduced } \\
\text { variety and } \\
\text { assortment }\end{array}$ \\
\hline & $\begin{array}{l}\text { Store size and } \\
\text { Layout }\end{array}$ & Prototype model & $\begin{array}{l}\text { Adjusted to } \\
\text { meet market } \\
\text { demant }\end{array}$ & Stable Size & Scaled down \\
\hline & Type of Store & Entrepreneurial & Aggres & Professional & Caretaker \\
\hline
\end{tabular}

Source: Lowry, J.R (1997) on Ioana Abrudan and Dabija, Christian (2009)
The four stages of lifecycle concept as mentioned above will study and identify how an age pattern can influence the existence of a shopping center. Atmosphere design as marketing tactic will also have to follow the lifecycle because it will have a different perception for each lifecycle. The difference is a result of advancement in time, technology and lifestyle, which also change visitors' view of the shopping center.

The research below will elaborate more about visitors' perspective regarding the atmosphere design of two shopping centers with different atmospheres because they were built in different eras, where atmosphere is regarded as one of the success factors of a shopping center (Wee and Tong, 2005).

\section{METHODS}

\section{Research through Exploration}

\section{and Use of Multiple Regression}

The research aimed to examine the relationship

between visitors' perception of atmosphere design

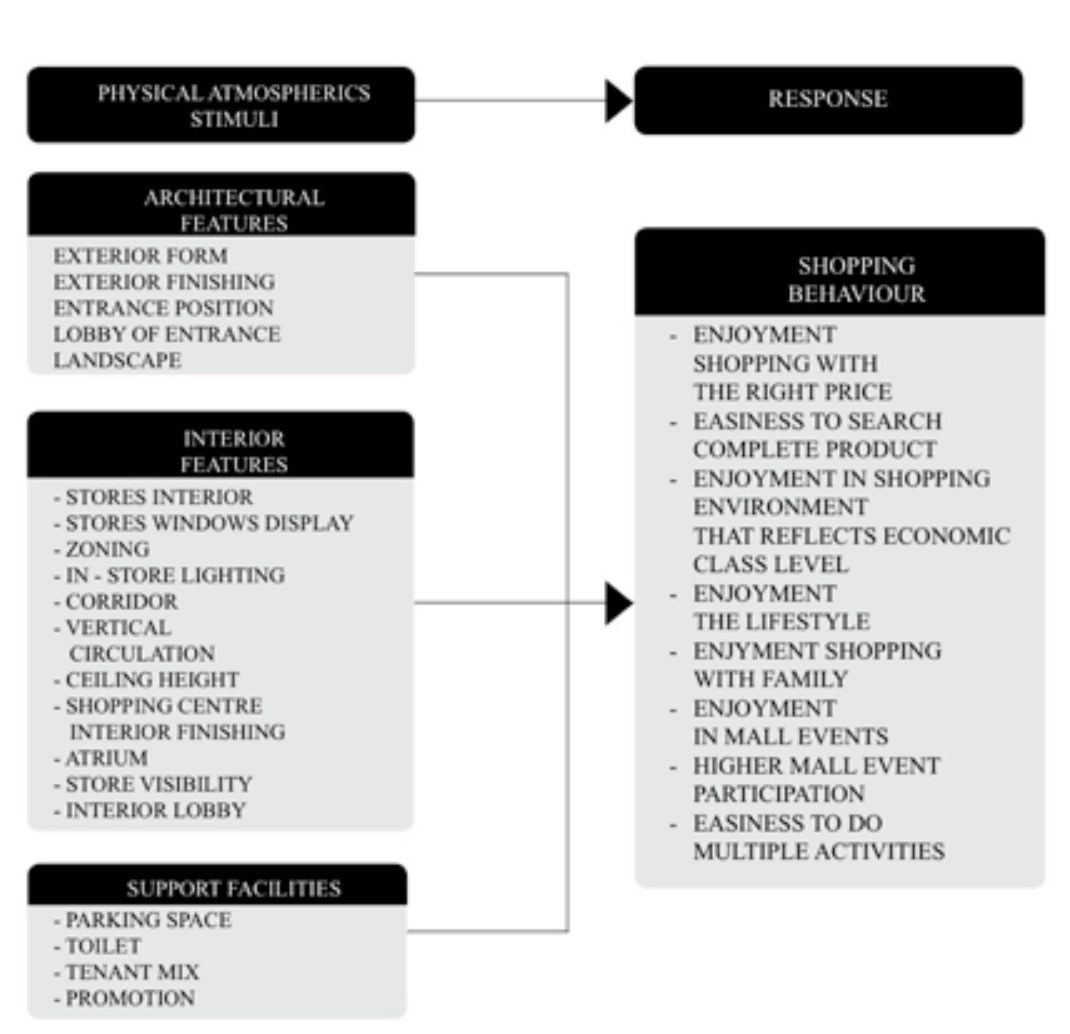

Image 3. Research Model as stimuli. It was done in two Surabaya shopping centers.

The research was divided into two stages: the first being the exploratory research and the second using multiple regression. The explorator research was done to recognize the attributes connected to consumers according to the design features attributes of Kramer (2008). The resultin attributes were then used for the second stage research which used multiple regression examine the relationship between them. Variables used in the research were independent variable and dependent variables where the variables from atmospheric stimuli could be defined as independent variables with exterior features, interior features and support facilities whereas dependent variable was visitors' behavior. The research model can be seen in the schematic below.

\section{Subject and Object of Research}

The research subject was the perception of 
shopping center's atmosphere design, obtained from 120 visitors in two shopping centers. Specifically, 60 people were surveyed in shopping center $\mathrm{X}$ and 60 people in shopping center $\mathrm{Y}$.

The research objects were two malls in Surabaya, one was built in the first era and the other in the most recent era, both of them have spatial characteristic as iconic architecture and stand on differen lifecycles. The two retail centers in Surabaya have a certain bond with people of the city but from the researcher's empirical point of view, the malls are considered relatively successful in fulfilling the criteria for a mall to show its existence. They are shopping center $\mathrm{X}$ (built in 2012, just entering launch phase/ innovation phase in lifecycle stage) and shopping center Y (built in 1987 and is still in growth phase /accelerated development to maturity in lifecycle stage) in Surabaya. Seen from their sizes the two are categorized as regiona super shopping centers, with a gross leasable area of more than 1,000,000 (in square feet), with three or more department store anchor tenants alongside discount and clothes stores as well as other specialty stores, and catering to the needs of more than 300,000 people.

\section{RESULTS AND DISCUSSION}

Multiple Regression on Mall X Data (Built in 2011) All of the data analyzed in this stage had gone through assumption test and was stated as normally distributed, with no multicollinearity, autocorellation and heteroskedasticity. Thi was then explained in three steps: multiple regression analysis which resulted in regression equation, influence of atmosphere design (with simultaneous variables of exterior features and building configuration, interior features, and support facilities) towards shoppers' shopping behavior, and partially examined the significance of these variables' contribution and finding its determination coefficient.

First, to find the influence of exterior features and building configuration $\left(\mathrm{X}_{1}\right)$, interior features $\left(\mathrm{X}_{2}\right)$ and support facilities $\left(\mathrm{X}_{3}\right)$ towards shopping behavior (Y), a double linear regression analysis was used with the following equation:

$$
Y=a+b_{1} X_{1}+b_{2} X_{2}+b_{3} X_{3}
$$

Where:

$\mathrm{Y}=$ Shopping behavior

$\mathrm{X}_{1}=$ Exterior Features and Building Configuration

$\mathrm{X}_{2}=$ Interior Features

$\mathrm{X}_{3}=$ Support Facilities

$\mathrm{a}=$ Constant

$\mathrm{b}_{1}, \mathrm{~b}_{2}, \mathrm{~b}_{3}=$ Regression Coefficient

Next, the result of software SPSS 13 for the double regression analysis is presented in the Table 2 .

According to the calculation on the above table, an equation of double linear regression was obtained:

$$
Y=0.950+0.148 X_{1}+0.353 X_{2}+0.215 X_{3}
$$

The regression coefficient value on the independent variables stated that if it is predicted that the independent variables has a one unit increment and the values of other independent variables are predicted to be constant or equal

Table 2. Multiple Regression Analysis

\begin{tabular}{ccccc}
\hline Variable & Regression Coefficient & Std. Error & $\mathbf{t}$ & Sig. \\
\hline (Constant) & 0.950 & 0.462 & 2.057 & 0.044 \\
\hline $\mathrm{X} 1$ & 0.148 & 0.105 & 1.404 & 0.166 \\
\hline $\mathrm{X} 2$ & 0.353 & 0.109 & 3.242 & 0.002 \\
\hline $\mathrm{X} 3$ & 0.215 & 0.094 & 2.295 & 0.025 \\
\hline
\end{tabular}

\begin{tabular}{|c|c|c|c|c|c|c|}
\hline F Count & df & F table & & & Description & conclution \\
\hline 12.766 & $\mathrm{df} 1=3$ & 2.769 & & & Ho rejected & Significant \\
\hline \multicolumn{7}{|c|}{ Table 4. Partial Hypothesis Test (Test $\mathrm{t}$ ) } \\
\hline Variable & $t$ count & df & t table & Sig & Description & conclution \\
\hline $\mathrm{X} 1$ & 1.404 & \multirow{3}{*}{56} & \multirow{3}{*}{ \pm 2.003} & 0.166 & Ho accepted & Not Significant \\
\hline $\mathrm{X} 2$ & 3.242 & & & 0.002 & Ho rejected & Significant \\
\hline $\mathrm{X} 3$ & 2.295 & & & 0.025 & Ho rejected & Signifikan \\
\hline \multicolumn{7}{|c|}{ Table 5. Model Summary ${ }^{\mathrm{b}}$} \\
\hline Model & $\mathrm{R}$ & \multicolumn{2}{|l|}{ R Square } & $\begin{array}{l}\text { ted } \mathrm{R} \\
\text { lare }\end{array}$ & \multicolumn{2}{|c|}{ Std. Error of the Estimate } \\
\hline 1 & $.637^{\mathrm{a}}$ & .406 & & 74 & .38819 & \\
\hline
\end{tabular}

Table 3. Overall Hypothesis Examination (Test F)

b. Dependent Variable: $Y$

zero, then the dependent variable is expected to go up or go down according to the regression coefficient mark of the independent variables

Second, in order to find the significance of the collective independent variables' influence mentioned above, test $\mathrm{F}$ was used and according to the SPSS calculation resulted in the Table 3.

From the Table 3, the value of $\mathrm{F}$ was calculated at 12.766. Because the calculated value of $F$ (12.766) $>\mathrm{F}$ in the table (2.769), then Ho was rejected. Therefore it can be concluded that simultaneously there is a significant influence of exterior features $\left(\mathrm{X}_{1}\right)$, interior features $\left(\mathrm{X}_{2}\right)$ and support facilities $\left(\mathrm{X}_{3}\right)$ towards shopping behavior $(\mathrm{Y})$.

Third, in order to find the significance of independent variables towards their independent variables, test $\mathrm{t}$ was used and according to the SPSS calculation resulted in the Table 4.

Fourth, to find out about the collective relation of the exterior features \& building configuration $\left(\mathrm{X}_{1}\right)$, interior features $\left(\mathrm{X}_{2}\right)$ and support facilities $\left(\mathrm{X}_{3}\right)$ towards shopping behavior $(\mathrm{Y})$, correlation analysis was used $(\mathrm{R})$.

According to the calculation output of SPSS software above, the correlation coefficient $(\mathrm{R})$ was calculated at 0.637 . This shows there is a strong relationship between architecture / exterior $\left(\mathrm{X}_{1}\right)$ interior features $\left(\mathrm{X}_{2}\right)$ and support facilities $\left(\mathrm{X}_{3}\right)$ towards shopping behavior $(\mathrm{Y})$.

The large influence of exterior features \& building configuration, interior features and suppor facilities towards shopping behavior is shown through the determination coefficient with the formula:

\section{$\mathrm{KD}=\mathrm{R}^{2} \times 100 \%$}

$$
=(0.637)^{2} \times 100 \%
$$

$$
=40.6 \%
$$

This means the variables of exterior features \& building configuration, interior features and support facilities contribute $40.6 \%$ towards the comfort level. Meanwhile, the remaining $59.4 \%$ of the comfort level can be explained through other variables which were not tested.

Multiple Regression on Mall Y Data (Built in 1987) First, to find the influence of exterior features and building configuration $\left(\mathrm{X}_{1}\right)$, interior features $\left(\mathrm{X}_{2}\right)$ and support facilities $\left(\mathrm{X}_{3}\right)$ towards shopping behavior (Y), a double linear regression analysis was used with the following equation

$\mathrm{Y}=\mathrm{a}+\mathrm{b}_{1} \mathrm{X}_{1}+\mathrm{b}_{2} \mathrm{X}_{2}+\mathrm{b}_{3} \mathrm{X}_{3}$ 
Where:

$\mathrm{X}_{2}=$ Interior Features

$\mathrm{X}_{3}=$ Support Facilities

$\mathrm{a}=$ Constant

$\mathrm{Y}=$ Shopping behavior

$\mathrm{X}_{1}=$ Exterior Features and Building Configuration

$\mathrm{b}_{1}, \mathrm{~b}_{2}, \mathrm{~b}_{3}=$ Regression Coefficient

Next, the result of software SPSS 13 for the double regression analysis is presented in the Table 6.

According to the calculation on the above table, an equation of double linear regression was obtained:

$Y=1.909+0.211 X_{1}+0.163 X_{2}+0.042 X_{3}$

The regression coefficient value on the independent variables stated that if it is predicted that the independent variables has a one unit increment and the values of other independent variables are predicted to be constant or equal zero, then the dependent variable is expected to go up or go down according to the regression coefficient mark of the independent variables

Second, in order to find the significance of the collective independent variables' influence mentioned above, test $\mathrm{F}$ was used and according to the SPSS calculation resulted in the Table 7.

From the Table 7, the value of $\mathrm{F}$ was calculated at 3.791. Because the calculated value of $F(3.791)$ $>\mathrm{F}$ in the table (2.769), then Ho was rejected. Therefore it can be concluded that simultaneously there is a significant influence of exterior features $\left(\mathrm{X}_{1}\right)$, interior features $\left(\mathrm{X}_{2}\right)$ and support facilities $\left(\mathrm{X}_{3}\right)$ towards shopping behavior $(\mathrm{Y})$.

Third, in order to find the significance of independent variables towards their independent variables, test $\mathrm{t}$ was used and according to the SPSS calculation resulted in the Table 8

Fourth, to find out about the collective relation of the exterior features \& building configuration $\left(\mathrm{X}_{1}\right)$, interior features $\left(\mathrm{X}_{2}\right)$ and support facilities $\left(\mathrm{X}_{3}\right)$ towards shopping behavior (Y), double correlation analysis was used (R)

According to the calculation output of SPSS software above, the correlation coefficient (R) was calculated at 0.637 . This shows there is a strong

Table 6. Multiple Regression Analysi

\begin{tabular}{ccccc}
\hline Variable & Regression Coefficient & Std. Error & $\mathbf{t}$ & Sig. \\
\hline (Constant) & 1.909 & 0.460 & 4.152 & 0.000 \\
\hline $\mathrm{X} 1$ & 0.211 & 0.150 & 1.407 & 0.165 \\
\hline $\mathrm{X} 2$ & 0.163 & 0.155 & 1.047 & 0.299 \\
\hline $\mathrm{X} 3$ & 0.042 & 0.120 & 0.349 & 0.728
\end{tabular}

Table 7. Overall Hypothesis Examination (Test F)

\begin{tabular}{cccccc}
\hline F count & df & F table & Sig & Description & Conclution \\
\hline \multirow{2}{*}{3.791} & $\mathrm{df1}=3$ & \multirow{2}{*}{2.769} & \multirow{2}{*}{0.015} & Ho rejected & \multirow{2}{*}{ Significant } \\
\cline { 2 - 3 } & $\mathrm{df2}=56$ & & & \\
\hline
\end{tabular}

Table 8. Partial Hypothesis Test (Test t)

\begin{tabular}{|c|c|c|c|c|c|c|}
\hline $\begin{array}{l}\text { Variable } \\
\end{array}$ & $t$ count & df & $t$ table & Sig & Description & conclution \\
\hline $\mathrm{X} 1$ & 1.407 & \multirow{3}{*}{56} & \multirow{3}{*}{ \pm 2.003} & 0.165 & Ho accepted & Significant \\
\hline $\mathrm{X} 2$ & 1.047 & & & 0.299 & Ho accepted & Significant \\
\hline X3 & 0.349 & & & 0.728 & Ho accepted & Not Significan \\
\hline
\end{tabular}

Table 9. Model Summary ${ }^{\mathrm{b}}$

\begin{tabular}{ccccc}
\hline Model & $\mathrm{R}$ & $\mathrm{R}$ Square & $\begin{array}{c}\text { Adjusted } \mathrm{R} \\
\text { Square }\end{array}$ & Std. Error of the Estimate \\
\hline 1 & $.411^{\mathrm{a}}$ & .169 & .124 & .44978 \\
\hline $\begin{array}{l}\text { a. predictors: (Constant), } \mathrm{X} 3, \mathrm{X} 1, \mathrm{X} 2 \\
\text { b. Dependent Variable: } \mathrm{Y}\end{array}$ & & & \\
\hline
\end{tabular}

relationship between architecture / exterior $\left(\mathrm{X}_{1}\right)$, interior features $\left(\mathrm{X}_{2}\right)$ and support facilities $\left(\mathrm{X}_{3}\right)$ towards comfort level (Y)

The large influence of exterior features \& building configuration, interior features and support facilities towards shopping behavior is shown through the determination coefficient with the formula:

$\mathrm{KD}$

$$
\begin{aligned}
& =R^{2} \times 100 \% \\
& =(0.411)^{2} \times 100 \% \\
& =16.9 \%
\end{aligned}
$$

This means the variables of exterior features \& building configuration, interior features and support facilities contribute $16.9 \%$ towards the comfort level. Meanwhile, the remaining $83.1 \%$ of the comfort level can be explained through other variables which were not tested.

Comparison between Two Shopping Centers Table 10 is a comparison between two shoppin centers which describes lifecycle stages, respondent characteristics, multiple regression equations and hypothesis examination on overall variables, partial hypothesis testing, determination coefficient and mean of related descriptive statistic of each variable.

There are several topics to discuss here, which are:

1. Both in the cases of shopping centers $X$ and $\mathrm{Y}$, it was proven that a shopping center atmosphere is related to shopping behavior.

2. In the case of shopping center $\mathrm{X}$, a facility recently built in 2012, it is different from the condition of shopping center $\mathrm{Y}$ which was built in the early era of shopping center boom in Surabaya in 1987. But both shopping center are considered successful to this day. The age of a shopping center influences its trendines because shopping activities are influenced by lifestyle and fashion. Shopping center in the innovation stage era tends to do extensive imaging and advertising efforts (Lowry, 1997). Therefore design in innovation stage becomes very important and acts as a competitive advantage in providing shopping experience. Shopping center in accelerated developmen and maturity phase stages usually only do a few maintenance and simple renovation works. Therefore perception towards atmospher can change along with the changes of era and age of a shopping center. This is evident in the determination coefficient of shopping center $X$ $(40,6 \%)$ which is bigger than shopping center Y (16,9 \%), where the mean value of shopping center $\mathrm{X}$ in various variables tend to be higher than shopping center $Y$.

3. Positioning of a shopping center also influence the atmosphere design of a shopping center. Shopping center $\mathrm{X}$ represents a lifestyle center with flexible forms so when surveyed, most of its visitors answered they went there for recreational purposes and relaxing with family, although some went with the main reason to shop (31.67\%). On the other hand, shopping center $\mathrm{Y}$, with a more functiona atmosphere, offers more preference for visitors with the main reason to shop ( $43 \%$ ). With longer operational time, various tenants and their locations are already known by visitors. Also select tenant combination that stays in keeping with the demands of visitor is the strength of shopping center Y. As a note, 
Table 10. Comparison between Two Shopping Centers in Surabaya

\begin{tabular}{|c|c|c|}
\hline Comparator & $\begin{array}{c}\mathrm{X} \\
\text { Shopping Center }\end{array}$ & $\begin{array}{c}\mathrm{Y} \\
\text { Shopping Center }\end{array}$ \\
\hline Lifecycle Stage & Innovation Stage & $\begin{array}{l}\text { Accelerated Development to } \\
\text { Mature Stage }\end{array}$ \\
\hline Respondent Characteristics & 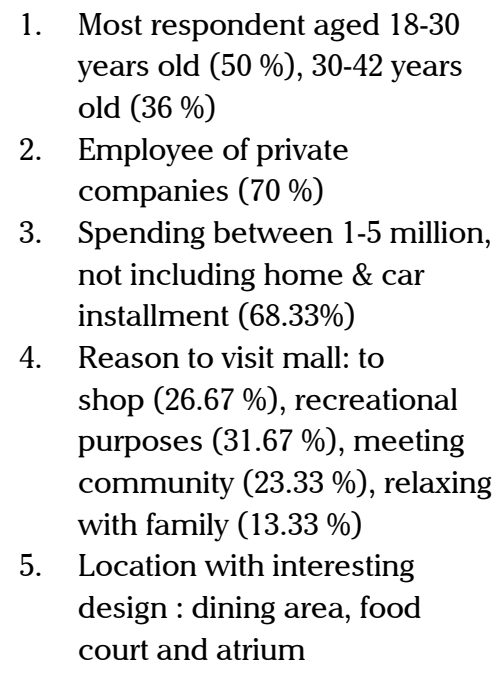 & 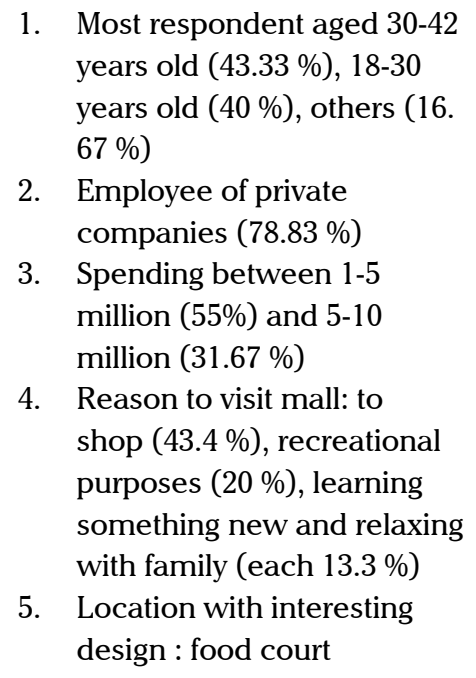 \\
\hline Multiple Regression Equation & $\begin{array}{l}Y=0.950+0.148 \mathrm{X}_{1}+0.353 \mathrm{X}_{2}+ \\
0.215 \mathrm{X}_{3}\end{array}$ & $\begin{array}{l}Y=1.909+0.211 X_{1}+0.163 X_{2}+ \\
0.042 X_{3}\end{array}$ \\
\hline $\begin{array}{l}\text { Hypothesis Testing on Overall } \\
\text { Variables }\end{array}$ & Significant & Significant \\
\hline Partial Hypothesis Testing & $\begin{array}{l}\text { X1 Not Significant } \\
\text { X2 Significant } \\
\text { X3 Significant }\end{array}$ & $\begin{array}{l}\text { X1 Not Significant } \\
\text { X2 Not Significant } \\
\text { X3 Not Significant }\end{array}$ \\
\hline Determination Coefficient & $40.6 \%$ & $16.9 \%$ \\
\hline $\begin{array}{l}\text { Mean of Architectural Features } \\
\& \text { Building Configuration }\end{array}$ & 3.850 & 3.450 \\
\hline Mean of Interior Features & 3.836 & 3.650 \\
\hline Mean of Support Facilities & 3.771 & 3.129 \\
\hline Mean of Shopping Behavior & 3.836 & 3.650 \\
\hline
\end{tabular}

it often conducts numerous activities at the same time in its premises.

4. In the simultaneous hypothesis testing centers, the results were the same. It means the three variables in a shopping center atmosphere (architectural features \& building configuration, interior features and support facilities) decidedly influence shopping behavior.

5. In the partial hypothesis testing, there is a on variables in both $\mathrm{X}$ and $\mathrm{Y}$ shopping difference between shopping center $\mathrm{X}$ and $\mathrm{Y}$. In shopping center $\mathrm{X}$, two variables (interior features and support facilities) partially affect shopping behavior while exterior features \& building configuration variable does not. This might be because most visitors' activities are centered in the interior space of the shopping center. While in shopping center $\mathrm{Y}$, none of the variables separately influences shopping behavior.

6. The mean value averages above the medium value (3) / average value so that it can be concluded that according tovisitors' perception both shopping centers have appearances that are above average. In shopping center $\mathrm{X}$ and $\mathrm{Y}$, the highest mean is in the interior variable with a value of 3.83 in shopping center $\mathrm{X}$ and 3.50 in shopping center $Y$. The lowest value in shopping center $\mathrm{Y}$ is in the support facilities variable with a value of 3.129 , as a result of the unchangeable architecture condition of the building so that the only thing that can be altered is the finishing material.

\section{CONCLUSION}

The conclusions that can be drawn here are:

1. There is a relationship between atmospher of a shopping center and shopping behavior where the value also depends on other factors that combine to determine the success of a shopping center such as location, visibility, ease of access, dimension, anchor tenant, tenant mix, image building strategy, marketing and management, and customers' oriented thinking pattern. Here, atmosphere of a shopping center is one of the success factors.

2. The lifecycle of a shopping center affect visitors' perception towards a shopping environment which will also be related to shopping behavior. The up-to-date quality o an atmosphere design provides a higher value regarding its influence on shopping behavior. A shopping center's design which is lifestyle and fashion oriented should also be renewed from time to time. But similar to the previous conclusion, shopping behavior is not only determined by shopping center atmosphere. There are also other factors not explored in this research.

3. Visitor characteristic factor (especially age and reason to visit) as well as the shopping center's character concept influence perception and appreciation toward shopping center atmosphere which also affect visitors' behavior.

\section{REFERENCES}

Abaza, Mona. (2001). Shopping Malls, Consumer Culture and the Reshaping of Public Space in Egypt. Theory. Culture, and Society, 16, 97-122.

Altman, Irwin dan Setha M. Low. (1992). Place Atttachment. Plenum Publishing Corp: New York

Berman \& Evans. (2001). Retailing Management, Prentice Hall: New Jersey.

Goss, Jon.(2010). The Magic of Mall: An Analysis of Form, Function and Meaning in the Contemporary Retail Built Environment. Annuals of the Association of American Geographers, 83, 1, 18-47.

Key Indicators for Asia and The Pacific 2010. http://www/adb.org/key-indicators/2011/main, diunduh pada tanggal 8 Mei 2012 Kotler, Philip (1973). Atmospherics as Marketing Tool. Journal of Retailing, 49,4, 48-64.

Kramer, Anita. ( 2008). Urban Land Institute. Retail Development: Wahington DC.

Kusumowidagdo , Astrid (1995). Analisis Pengaruh Persepsi Atas Variabel-Variabel Store Atmosfer Terhadap Store Choice Pada Pengunjung Fashion Retail di Supermal Pakuwon Indah Surabaya. Thesis Tak Diterbitkan. Program Magister Manajemen Universitas Airlangga: Surabaya.

Kusumowidagdo, Astrid (2009). Perbedaan Persepsi Secara Gender Atas Desain Toko Ritel Terhadap Perilaku Belanja Penelitian Tak Diterbitkan. Universitas Ciputra: Surabaya.

Kusumowidagdo, Astrid (2010). Desain Ritel. Gramedia Pustaka Utama: Jakar

Levy \& Weitz (1998). Retail Management. McGraw-Hill: New York.

Lowry, James.R. (1997) The Lifecycle of Shopping Centres. Business Horizon. 
Mattila, Anna S., \& Wirtz, Jochen. (2001). Congruency of Scent and Music as a Driver of In Store Evaluations and Behaviour. Journal of Retailing. 77, 273-289.

Majalah Arti, Edisi 31, Tahun 2010, September 2010.

Marketing Mix, 07/IX/ Juli 2009. Retail dengan Experience.

Ma'ruf Hendry (2005). Pemasaran Ritel. Gramedia Pustaka Utama: Jakarta

Mehrabian, Albert., \& Russel, James A (1974). An Approach to Environmental Psychology. MIT Press: Cambridge, MA.

Nicoleta, Abrudan Ioana \&, Christian, Dabija Dan (1997) The Lifecycle Shopping Centres and Possible Revitalization Strategies. Peter, Paul \& Olson, Jerry (2002). Consumer Behaviour and Marketing Strategy: sixth edition. Ney York: McGraw Hill.

Pine \& Gilmore (1998). Welcome To The Experience Economy. Harvard Business Review, Juni-August, 97-105.

Staeheli, Lynn A \& Mitchell. (2006). USA's Destiny? Regulating Space and Creating Community in American Shopping Malls. Urban Studies, 43, 5/6, 977-992.

Steele, Fritz. (1981). The Sense of Place. Boston: CBI Publishing Company, Inc.

Stokols \& Altman (1984). Handbook of Environmental Psychology. John Wiley and Sons : New York.

The Markeeters. (2012) Demand Jauh Di Atas Supply, Februari, 22.

Turley, L.W \& Milliman, Ronald. (2000). Atmospherics Effect on Shopping Behaviour: A Review Of The Experimental Evidence. Journal Of Business Research, 49, 193-211.

Wee \& Tong, (2005). The 4RS of Asian Shopping Centre Management, PT Buana Ilmu Populer: Jakarta.

Williams (2006). Design for Experience: A New Rationale. Journal of Design Education and Technology. 2, 2, 9-19. 